\title{
Teachers Practice of Human Rights in Jordan
}

\author{
Mohammad Sayel Alzyoud \\ Dean and Professor of Educational Foundations, School of Education \\ The University of Jordan, Amman
}

Tel: 962-777-111-450Ｅ-mail:malzyoud@ju.edu.jo

\author{
Mervat Saleh Abu Salah \\ Assistant Professor, UNRWA School, Amman
}

Tel: 962-7-9917-5950Ｅ-mail: mirvatdana4ever@yahoo.com

\author{
Bilal Mohammed Salah Sulaiman \\ Assistant Professor, Department of Educational Psychology \\ Irbid University College- University of Balqa Applied University \\ E-mail: Bilalbanyhamad@gmail.com
}

Received: May 8, 2020

Accepted: June 17, 2020

Published: August 1, 2020

doi:10.5296/jse.v10i3.17003

URL: https://doi.org/10.5296/jse.v10i3.17003

\begin{abstract}
The aim of this study is to identify the degree to which the teachers of UNRWA in Jordan practice human rights from the point of view of the students. The study sample consists of 2505 students from a population of 46636 students from UNRWA schools. This was performed in the four educational districts of the Agency in the second semester of the academic year 2016/2017. To achieve the objectives of the study, a questionnaire was constructed to determine the degree to which UNRWA teachers in Jordan have been practicing the principles of human rights from the students' point of view. After verifying the validity of the questionnaire, it was applied on the study personnel. To answer the questions of the study, statistical methods were carried out using the SPSS program to process the data. The mean, the standard deviations, the levels of the scales, the fields, and the instrument were used to answer the first question. To answer the second question, three-way MANOVA, and least significant difference (LSD) were used. The results of the study on the first question
\end{abstract}




\section{Macrothink}

indicated that the degree of practice of the teachers of UNRWA schools in Jordan of the principles of human rights from the point of view of their students was divided into three major areas: classroom and extracurricular activities, Teacher behavior and assessment methods, learning objectives and learning content. There are statistically significant differences in the degree of practice of the principles of human rights and the three fields according to the gender variable in favor of females. Also, a statistical significance difference also exists in the fields based on the degree of exercise of the three principles of human rights. It also has to do with the total degree of the questionnaire according to the variable grade between seventh grade students and eighth, ninth, and tenth grade students in favor of seventh grade students. On the other hand, there were no differences between students in the eighth, ninth, and tenth grades. In addition, there were statistically significant differences in the overall degree of the UNRWA teachers' training according to the school site variable. Based on the results of the study, a number of recommendations were presented, including the exchange of experiences between male and female schools to develop the sharing of ideas, activating the role of community institutions that deal with human rights issues, and linking them to channels of communication with schools by intensifying visits. It also entails giving greater attention to the celebration of international, as well as national events related to human rights, and to give a greater share of the financial budget, moral, material, equipment, environmental, resources material, human, and symbolic.

Keywords: Human, Rights, Education, UNRWA, Schools, Teachers, Jordan 


\section{Introduction}

God's creation of man and his honoring of all creatures is a blessing and a grant not denied by a thinking mind in the event of this life. Also, God has granted rights to people to ensure they are living right. Another grant came from the fact that man is incapable of building the earth before living a dignified life, which gives him stability. Humans, however, have been deprived of their human rights to perform their duties in the building of the earth. Hence, human rights are fundamental rights for all people as human beings, and they need their rights to live in dignity. These rights are universal, equal, interdependent, and indivisible.

These rights became a global issue at all levels. During World War II, after humanity had tasted the horrors of previous wars, States stood up to try to correct mistakes. They are wanted to make their people miserable and humiliated. As a result, it collapsed into international human rights regulations, which were represented in the Universal Declaration of Human Rights in 1948. In addition, it came after The International Covenant on the Rights of Individuals in the Economic, Social and Cultural Rights (1966), which are the basis for the international understanding of the importance of human rights and the need to respect them (Ishay, 2008). Despite these charters and other universal steps that places emphasis on the importance of respect for human rights, serious violations of these rights have been observed everywhere. Thus, this has necessitated the need for awareness of the meaning, substance, and application of the term "human rights" contained in the preamble to the Universal Declaration of Human Rights. It states that the education and learning of human rights is a duty, a right and a responsibility, and the pursuit of the integration of these rights means the creation of an environment that respects these rights, which obligates all individuals, communities, and bodies to respect the rights granted to everyone and respect their freedoms. To adopt educational strategies derived from this Declaration, despite the differences over the degree of importance of education on these rights in many countries, this topic have a voice and echo. Thus, this has called for the existence of committees to protect human rights, and to prevent violations and the preparation of reports and observations on the effectiveness of the application of rights and grants to individuals. It has brought about the monitoring and revision of the work of many governments and organizations that have the duty to preserve and protect human rights (Perry, 1998). The importance of this education is reflected in the international conventions that stipulate the need for an educational policy in the school system. This view of human rights, including the Convention on the Rights of the Child, is strong. Article 28 calls for the need for educational policies that are consistent with the dignity and humanity of the child, skills and the abilities of children so as to form a capable human personality. In addition to promoting understanding between the different races and nationalities irrespective of their religion, color and language, the right is given to all humanity. When the educational mechanism adopted by the institutions of socialization is applied in order to consolidate human rights principles, attention is drawn to various strategies that need to be adopted so as to acquire skills. This forms the basis for dealing with this type of value education, which ensures that students can play their roles in the culture of human rights. Therefore, it requires the establishment of experimental education. 
Human rights committees and bodies have been able to take advanced steps in the defense of individual rights, including UNESCO, which launched the Declaration of Principles on Tolerance in 1995. Consequently, they referred to the importance of tolerance as an important condition for achieving peace, development, and the advancement of nations. The United Nations had the upper hand in human rights education from a global perspective. Based on the discussions at the International Conference on Human Rights held in Vienna in the early 1990s, references were made to the vital role that educational institutions play in social education and human rights education. The aim of the conference is to impart to individuals the skills, values, and knowledge that would enhance understanding and respect. It also involves the effective exercise of these rights, which means that there is the need to find new ways and mechanisms for the new education (Gidori, 2012). In 2002, UNRWA began a human rights development project at UNRWA schools through a program that builds strategies for opening up peaceful communications, finding solutions to conflicts, seeking tolerance, and maximizing its role through educational curricula and guides, and integrating human rights training activities and courses. This is aimed at encouraging students and teachers to contribute to the dissemination and application of this knowledge, and also to provide an educational environment based on dialogue with the aim of spreading the culture of acceptance based on differences in opinion (UNRWA, 2007).

The researchers differed in regards to defining the term "human rights". Hence, this difference is due to the diversity of their vision and specialization. Mr. (2000) defines human rights as those rights enjoyed by man, just because he is human. These rights are recognized by man without regard to his nationality, religion, social status or economic status. They are natural rights owned by man. Even before he becomes a part of a particular population, this rights precedes the state and he can lay claims on it. Human rights can be defined as the set of rights that are closely related to the human personality as laid down in the international charters and enjoyed by man, and may not be stripped of them for any reason, apart from all its manifestations (Juliell, 2002). They have also been defined as those rights already enjoyed and practiced by individuals and groups, irrespective of the official commitment of Governments to international conventions and treaties to protect and care for human and human rights. They refer to the interests and freedoms that an individual or community expects from a population in accordance with the norms of this population, i.e. the advantages that the individual or group feels they have the right to receive from a population (Arab Organization for Human Rights, 2003). Based on the definitions of human rights, it is clear that the term "human rights", like other human sciences, cannot be defined as comprehensive. This is because it is constantly evolving with the development of the circumstances at either the international, regional or local levels, or based on the political level or legal status.

The concept of human rights education is imperative to promote and achieve stable and harmonious relations among local communities and to consolidate mutual understanding, tolerance, and peace in 1993 as part of the World Conference on Human Rights. In 1994, the General Assembly of the United Nations adopted a ten- in 1995-2004, and urged Members to strengthen training and promote a global human rights culture. Based on these 
recommendations and innovations, human rights organizations and other organizations have come up with many definitions that included the essence and the meaning of human rights education. These include the definition of Amnesty International, which is a process that introduces people to their rights and the rights of others within a participatory and interactive learning framework (Amnesty International, 2004). The comprehensive education of human rights seeks not only to provide knowledge about human rights and to define and protect the means of protecting them, but also to transfer the necessary skills to promote, defend, and apply human rights in life, and also to strengthen the attitudes and behaviors necessary to support the human rights of all individuals (UN, 2005).

Education on the rights, values, and principles of human rights is an educational project to enable people to learn the basic knowledge necessary to make them reject the forms of oppression, slavery, and injustice, and to enhance their sense of responsibility towards their rights, considering the individual interest without prejudice to public interests. Others within the framework of learning, based on mutual participation and interaction, focus on changing attitudes and behavior, learning new skills, and promoting knowledge sharing and experience. Subsequently, this education has acquired characteristics based on its advantage from other educational processes. It is a humane education, oriented towards human awareness of its rights. It is the essence of the existence of human self, and education for human, in order to ensure the realization of its essence (Jabri, 1989). It is a rational enlightenment education that is based on a rational enlightenment that seeks to consolidate and establish its human discourse. However, this is based on the concepts of self and mind, freedom, tolerance, difference, dignity, and equality. It expresses a liberal thought that stems from the same person as a rational being, and it also aims to enlighten thoughts, minds, and relations (Odigye, 1998). Furthermore, it is a critical education with a critical dimension that tends to rethink the different values, principles, and behaviors that are contrary to the rights of individuals and it impedes the exercise and respect of rights. It seeks to bring about a profound change in the traditional practices of education and in thinking methods (Moroccan Ministry of Education, 1998). It has modern dimensions that include the principle of openness of the personality of the learner on his living environment. Also, it seeks to create a citizen who believes in the values of human rights, respects them and recognizes the rights of others, rejects what is contrary to them and that contradicts their existence and preserves them, and it seeks to practice the behaviors that they apply in practice without compromising the rights of others (ICE 1995). Additionally, it directs them in order to teach the behaviors established by these values, and also addresses their discourse and practices to address human being as a practitioner of practical behavior, and not a thinker in a theoretical manner (Balawi, 2001).

The teacher's ability to teach the material to his student makes him gain great respect and consideration by his student. Thus, this facilitates the impact of intellectual and moral aspects in them. Combined with the ability to be distict in his behavior and reflect his confidence and faith in human rights policies and respect, it opens the way to instill values in terms of rights. The teacher's skills, awareness, and culture can result to the most important roles in the educational process on human rights. The successful teacher which is distinct in this 
education is the teacher that possesses the basic theoretical knowledge, the practical applied behaviors, and the ability to use them and harness them in their appropriate positions and contexts. Here, this gave birth to the occasion to achieve the desired goal (Jarbawi, 2001). The teacher's performance and excellence in this field is linked to his focus on how to achieve his goal of actual education of human rights with his student. The teacher also seeks to find the incentives that guide his behavior with students, and also to possess skills as well as professional and educational qualifications that facilitate his work in the management of the classroom environment. According to its quality, consistency, and its use of innovative strategies for teaching, it seeks dialogue among themselves. Nevertheless, these means have a significant direct influence on students (Kut \& Mousa, 2004). Paintings, images, and human rights expressions influence the physical environment that is based on the teacher's performance. Here, the teacher seeks to employ the means and cards in the learning process, translates the generalization of the goals of human rights education into procedural qualitative objectives, adjusts the theoretical content of the knowledge in its curriculum, identifies its basic elements, and appropriate educational means of communication for these materials and their specificity (Ismail, 1999).

The most important base on which human rights education is based is the establishment of the values of rights and their translation into practice behaviors, and strong convictions in the minds of students, as well as endorsing it into their feelings. Subsequently, this means that education has risen to a new level which carries behavioral moral education (Mohsen, 2004). This goal will not be achieved unless the school, which is a vital social education institution, plays a significant role in spreading a culture of tolerance and respect, accepting the other, and opening dialogue between the students and the faculty. Therefore, there is a need for programs, activities, and educational curricula that establishes this culture and allows students to exercise their rights and to recognize them as their inherent right. The integration in the field of education is manifested in the interplay between the elements of the educational process. Here, the players are students, teachers, the school environment, and the family who seeks to achieve the same values. They also seek the reasons behind instilling a culture that accepts different viewpoints to embody the rejection of violence. Dialogue also has a significant impact on the life of the individual and population. Human rights do not only stand on the theoretical side of the right, but also have an overlapping aspect with many values such as the concept of tolerance, diversity, privacy, and the same group. Nevertheless, they rely on various means of dialogue and communication, without fanaticism of personal ideas to enable individuals and societies to find a way to live peacefully and stay away from violence (UNRWA, 2018). Conditions should be provided for the dissemination and application of such education in the school environment, and to restore practices that reflect respect for human rights, such as the relationship between teacher and student, the imposition of penalties for acts that violate the right to the individual, the promotion of the exercise of human rights games and activities, and the integration of this culture into the cultural activities of daily lessons. However, it also aims to acquire the characteristics required by citizenship and active democracy. This is in addition to preparing opportunities to simulate the experiences of democratic life, to learn the meaning of pluralism and acceptance of the other and respect differences, exercise the right to vote and to make opinions, follow the 
rational ways of dialogue, and the logical connection between the application of their rights and the fulfillment of their duties (Victory, 2000). UNRWA schools in Jordan are schools that are concerned with human rights education and that transform it from theory to practice. UNRWA seeks to provide human rights education to its students by providing quality education with effective citizenship. Hence, this education is based on international human rights principles and standards. This helps in ensuring similarity to what is being practiced throughout the world. This education is directed by teachers and administrators, reflecting the concept of a human right-based environment and living with dignity and respect with the use of questionnaire $\mathrm{s}$ and activities that embody the principles of human dignity, equality, universality, participation, integration, tolerance, and conflict resolution (UNRWA, 2007).

\subsection{Problem Statement}

The problem of the study is to identify the reality of the teachers' practice of human rights principles with their foresight because of studies that indicates that these practices are low in UNRWA schools in all regions. A group of experts on human rights education in UNRWA schools - Thomson, Bonnet and Pontfort - conducted a study in 2013 to find out the causes of school dropout in UNRWA schools in all areas. The results of this study showed that the dropout rate in the UNRWA schools in Jordan reached 56\% of the students in grades 7-10. The reasons for this dropout were associated with corporal punishment, lack of interest of teachers, early marriage of girls, low level of achievement, and practices of teachers that lack respectful treatment and rights. Thus, this fact led the researcher to adopt the subject of this study and to seek to explain this reality by answering the following questions:

1. What is the degree to which UNRWA school teachers in Jordan are practicing the principles of human rights from the students' point of view?

2. Does the degree of the practice of UNRWA school teachers differ in terms of gender, grade and school location for students at the level of $\alpha=0.05$ ?

\subsection{Objectives of the Study}

The aim of this study was to demonstrate the degree to which UNRWA teachers in Jordan were practicing human rights principles with their students. Thus, this study was carefully formulated with the following objectives:

- Recognize the degree to which UNRWA school teachers in Jordan are practicing the principles of human rights from the students' point of view.

- To determine whether the degree to which UNRWA school teachers practice human rights principles varies according to Gender, grade, and location of the school according to the students.

\subsection{The Importance of the Study}

The importance of the study is to help educational professionals to judge the appropriateness of the systems, activities, and methods used for education for human rights. It also provides 
some scientific questionnaire $\mathrm{s}$ that can be used and aims to use their steps in carrying out similar studies.

Consequently, its importance lies on its emphasis on the right of student's education on human rights and its principles as an inherent right in the Universal Declaration of Human Rights for everyone in general and UNRWA students in particular. It also shows the quality, effectiveness, and reality of education on the principles of human rights in UNRWA schools based on the results of questionnaires. Thus, this shows the degree of teachers' Principles so as to develop this reality and promote it.

\subsection{Definition of Terms}

Practice: The set of activities, behaviors, perceptions, beliefs, teachings, and values that must be performed in a particular function, which are also the duties, tasks, and responsibilities of an employee's role (Domo, 1990, p. 87). The procedural definition of the degree of practice, as included in this study, refers to the task that the school and teachers should undertake to develop the human rights values of the students as measured by the results of the study questionnaire.

2. Human Rights: Human rights are the fundamental criteria under which people without dignity cannot live as human beings and are the foundation of freedom, justice and peace, and that respect for them will allow for the full development of the individual and population (Amnesty International, 2004).

3. UNRWA Schools: United Nations Relief and Works Agency, which is aimed to assist Palestinian refugees in Jordan, provides basic education to more than 115,000 students in 171 UNRWA schools.

4. Human Rights Principles: These are skills and information aimed at building a global culture of human rights through the exchange of knowledge, the transfer of skills, the formation of trends aimed at promoting respect for rights and freedoms, the full development of the human personality and the sense of dignity, and the promotion of concepts of understanding, tolerance, equality, gender, and friendship among peoples. It is an active participation in a free and rule-based population, peace-building and maintenance, the promotion of people-centered sustainable development, and the promotion of social justice (Al Jarbawi, 2001).

\subsection{The Study Limitation}

1. This study was limited to UNRWA schools in Jordan.

2. This study was applied in the second semester of the academic year 2016/2017.

3. This study included the members of the study sample who are students of UNRWA schools in the seventh, eighth, ninth and tenth grades, males and females.

4. This study was limited to concepts related to human rights, which will be derived from the theoretical literature and programs implemented in UNRWA schools. 


\section{Methodology}

The descriptive approach was used in this study. Consequently, the degree to which UNRWA school teachers in Jordan studied the principles of human rights from the students' point of view was examined.

\subsection{Population and Sample}

The study population consists of students of the upper secondary stage of grades 7, 8, 9 and 10. All were in UNRWA schools in Jordan in the second semester of the academic year (2016/2017) and in the four educational districts in Jordan (south Amman, North Amman, Irbid, Al-Zarqa) which reached 46636. Table 1 shows the distribution of the study population according to their variables.

Table 1. Distribution of the study population by gender, grade, and school location

\begin{tabular}{|c|c|c|c|c|}
\hline The number & Study variables & Categories & Quantity & The ratio \\
\hline \multirow[t]{2}{*}{1} & \multirow[t]{2}{*}{ Gender } & Male & 21452 & $46 \%$ \\
\hline & & Female & 25184 & $54 \%$ \\
\hline \multirow[t]{4}{*}{2} & \multirow[t]{4}{*}{ Class } & $7^{\text {th }}$ grade & 12429 & $26 \%$ \\
\hline & & $8^{\text {th }}$ grade & 12462 & $27 \%$ \\
\hline & & $9^{\text {th }}$ grade & 11421 & $24 \%$ \\
\hline & & $10^{\text {th }}$ grade & 10324 & $22 \%$ \\
\hline \multirow[t]{6}{*}{3} & \multirow{5}{*}{$\begin{array}{l}\text { Location of } \\
\text { study }\end{array}$} & Irbid & 11062 & $24 \%$ \\
\hline & & South Amman & 13415 & $29 \%$ \\
\hline & & North Amman & 12410 & $27 \%$ \\
\hline & & Amman & & \\
\hline & & Al-Zarqa & 9749 & $20 \%$ \\
\hline & \multicolumn{2}{|l|}{ Total } & 46636 & $100 \%$ \\
\hline
\end{tabular}

The sample of the study consisted of 2505 students, who were selected in simple random way, i.e. $55 \%$ of the study population. Table 2 shows the distribution of the sample of the study according to its variables. 


\section{Macrothink}

Table 2. Distribution of the sample of the study by gender variable, grade, and location of the school

\begin{tabular}{|c|c|c|c|c|}
\hline Number & Variable & Categories & Quantity & Percentage \\
\hline \multirow[t]{3}{*}{1} & \multirow[t]{2}{*}{ Gender } & Male & 1257 & $50 \%$ \\
\hline & & Female & 1248 & $50 \%$ \\
\hline & \multicolumn{2}{|l|}{ Total } & 2505 & $100 \%$ \\
\hline \multirow[t]{5}{*}{2} & \multirow[t]{4}{*}{ Class } & $7^{\text {th }}$ & 505 & $20 \%$ \\
\hline & & $8^{\text {th }}$ & 660 & $26 \%$ \\
\hline & & $9^{\text {th }}$ & 698 & $28 \%$ \\
\hline & & $10^{\text {th }}$ & 642 & $26 \%$ \\
\hline & \multicolumn{2}{|l|}{ Total } & 2505 & $100 \%$ \\
\hline \multirow[t]{2}{*}{3} & \multirow{2}{*}{$\begin{array}{l}\text { School } \\
\text { Location }\end{array}$} & City & 1343 & \\
\hline & & Camp & 1162 & $54 \%$ \\
\hline
\end{tabular}

\subsection{Study Questionnaire}

It is a questionnaire built to measure the degree to which UNRWA teachers and teachers have been able to observe the principles of human rights from the students' point of view. The final form consists of forty-eight paragraphs divided into three sub-dimensions: classroom and extracurricular activities; teacher behavior; and evaluation methods. Also, it was built by the following steps:

1. A review of the theoretical literature on human rights principles was carried out. An inductive method was used to identify the areas of the questionnaire. The studies dealing with human rights principles were summarized and the most commonly used behavior in the teaching of human rights principles was enumerated. Three main areas were identified: classroom and extracurricular activities, Teacher behavior and assessment methods, learning objectives and learning content.

2. Prepare the questionnaire in its preliminary form and submit it for arbitration in order to verify its authenticity.

3. Application of the questionnaire to a group of students in grades 7,8,9 and 10, from outside the study sample, to determine the ambiguity in the paragraphs, the appropriateness of the linguistic formulation of the students' level, and to take notes as well as study the psychometric characteristics of the questionnaire .

4. Extracting the questionnaire in its final form after obtaining the results of the study based on honesty and consistency. 


\subsubsection{Questionnaire Validity}

The content validity of the questionnaire was confirmed by presenting it in its initial form (60) paragraph to twenty arbitrators with expertise in Jordanian. This is aimed at determining the suitability of the paragraphs for the measurement of each of the domains to which they belong, in addition to determining the suitability $(80 \%)$ as a ratio of agreement between the arbitrators on one paragraph. In the light of this criterion, some paragraphs (12) were deleted and some paragraphs were modified in terms of language. Thus, the number of paragraphs came into being after the opinions of the arbitrators (48) paragraph. The validity of the paragraph (Item Validity) was determined by calculating the correlation of the paragraph to the degree to which it belongs and to the total score of the instrument. Thus, the results are shown in Table 4.

\begin{tabular}{|c|c|c|c|c|c|c|c|}
\hline Field & $\begin{array}{l}\text { Degree of } \\
\text { relevance to } \\
\text { the overall } \\
\text { degree }\end{array}$ & $\begin{array}{l}\text { The degree to } \\
\text { which they } \\
\text { relate to the } \\
\text { domain to } \\
\text { which they } \\
\text { belong }\end{array}$ & $\begin{array}{l}\text { Para } \\
\text { grap } \\
\text { h } \\
\text { Num } \\
\text { ber }\end{array}$ & $\frac{\mathrm{D}}{\mathrm{e}}$ & $\begin{array}{l}\text { Degree of } \\
\text { relevance to } \\
\text { the overall } \\
\text { degree }\end{array}$ & $\begin{array}{l}\text { The degree to } \\
\text { which they } \\
\text { relate to the } \\
\text { domain to } \\
\text { which they } \\
\text { belong }\end{array}$ & $\begin{array}{l}\text { Paragraph } \\
\text { number }\end{array}$ \\
\hline \multirow{10}{*}{$\begin{array}{r}\text { Extracurricul } \\
\text { ar } \\
\text { Activities }\end{array}$} & $0.53 * *$ & $0.61^{* * *}$ & 25 & \multirow{10}{*}{ 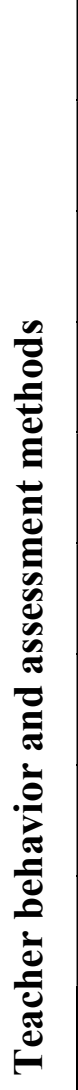 } & $0.39^{*}$ & $0.50^{* *}$ & 1 \\
\hline & $0.66 * *$ & $0.72 * *$ & 26 & & $0.46^{* *}$ & $0.53^{* *}$ & 2 \\
\hline & $0.64 * *$ & $0.36 *$ & 27 & & $0.39^{*}$ & $0.47^{* *}$ & 3 \\
\hline & $0.54 * *$ & $0.41 *$ & 28 & & $0.41^{*}$ & $0.42^{*}$ & 4 \\
\hline & $0.53 * *$ & $0.53 * *$ & 29 & & $0.46^{*}$ & $0.53^{* *}$ & 5 \\
\hline & $0.55^{* *}$ & $0.40 *$ & 30 & & $0.56^{* *}$ & $0.51^{* *}$ & 6 \\
\hline & $0.53 * *$ & $0.69 * *$ & 31 & & $0.43^{*}$ & $0.46^{*}$ & 7 \\
\hline & $0.69 * *$ & $0.50 * *$ & 32 & & $0.36^{*}$ & $0.38^{*}$ & 8 \\
\hline & $0.53 * *$ & $0.40 *$ & 33 & & $0.56^{* *}$ & $0.42^{*}$ & 9 \\
\hline & $0.72 * *$ & $0.40 *$ & 34 & & $0.49^{* *}$ & $0.57^{* *}$ & 10 \\
\hline
\end{tabular}




\begin{tabular}{|c|c|c|c|c|c|c|}
\hline $0.44 *$ & $0.42 *$ & 35 & \multirow{14}{*}{ 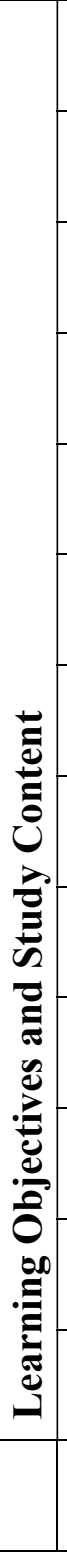 } & $0.73^{* * *}$ & $0.64^{* *}$ & 11 \\
\hline $0.55^{* *}$ & $0.53 * *$ & 36 & & $0.38^{*}$ & $0.59^{* * *}$ & 12 \\
\hline $0.44 *$ & $0.42 *$ & 37 & & $0.52^{* * *}$ & $0.55^{* *}$ & 13 \\
\hline 0.33* & $0.58 * *$ & 38 & & $0.74^{* *}$ & $0.76^{* * *}$ & 14 \\
\hline $0.45^{*}$ & $0.39 *$ & 39 & & $0.71^{* * *}$ & $0.71^{* *}$ & 15 \\
\hline $0.71 * *$ & $0.61 * *$ & 40 & & $0.65^{* *}$ & $0.64^{* * *}$ & 16 \\
\hline $0.63 * *$ & $0.67 * *$ & 41 & & $0.60^{* * *}$ & $0.65^{* * *}$ & 17 \\
\hline $0.37 *$ & $0.50 * *$ & 42 & & $0.48^{* *}$ & $0.57^{* *}$ & 18 \\
\hline $0.59 * *$ & $0.64 * *$ & 43 & & $0.75^{* *}$ & $0.72^{* *}$ & 19 \\
\hline $0.44^{*}$ & $0.51 * *$ & 44 & & $0.56^{* *}$ & $0.67^{* *}$ & 20 \\
\hline $0.62 * *$ & $0.58 * *$ & 45 & & $0.53^{* *}$ & $0.71^{* *}$ & 21 \\
\hline $0.58 * *$ & $0.52 * *$ & 46 & & $0.60^{* *}$ & $0.50^{* *}$ & 22 \\
\hline $0.66 * *$ & $0.73 * *$ & 47 & & $0.61^{* *}$ & $0.80^{* *}$ & 23 \\
\hline $0.44 *$ & $0.65 * *$ & 48 & & $0.60^{* * *}$ & $0.72^{* * *}$ & 24 \\
\hline
\end{tabular}

It is noted from Table 3 that the correlation coefficients of the vertebrates in the field of class and extracurricular activities ranged between $0.38-0.76$ and that the field correlation coefficients in the total degree of the questionnaire ranged between $0.36-0.74$. As for the field of the teacher's behavior and the methods of evaluation, the correlation coefficients of the vertebrates ranged between $0.36-0.80$. The field correlation coefficients ranged from 0.53 - 0.75. In the field of learning objectives and the study content, the correlation coefficients of the vertebrates ranged from 0.39 to 0.72 , whereas the field correlation coefficients ranged from 0.33 to 0.71 . These correlations were significant at $\alpha=0.05$. A criterion for the acceptance of a paragraph was adopted with a coefficient of no less than 30.0. It can be said that the reliability coefficient of this amount is acceptable in the general balance of correlation coefficients (Gronlund, 1981). Based on this criterion, all paragraphs of the scale were accepted such that the number of paragraphs of the questionnaire remained in its final form (48) paragraphs. 


\subsubsection{Reliability of the Questionnaire}

It was confirmed that the study instrument was stable based on the manner of repetition. The scale was applied to 30 male and female students from outside the study sample and was re-applied to the same sample for two weeks. The Pearson correlation coefficient was calculated between the first application and the second application. The correlation coefficient for the subdivisions ranged between 0.84 and 0.91 and the total value was 0.89 . These were statistically significant at $\alpha=0.05$ (Gronlund, 1981) for the three subfields and for the instrument. The results showed that the persistence parameters using the Cronbach alpha equation for the sub-dimensions ranged from 0.74 to 0.86 and to the scale in total (0.91), indicating that the questionnaire has suitable reliability parameters for the purposes of this study (Table 4).

Table 4. Repetition reliability and internal consistency coefficients Cronbach Alpha for the degree of human rights practice of UNRWA school teachers from the point of view of students

\begin{tabular}{|r|r|r|}
\hline Field & Repetition Stability & Internal Consistency \\
\hline Classroom and extracurricular activities & 0.91 & 0.91 \\
\hline Teacher behaviors and methods of & 0.84 & 0.84 \\
assessment & & 0.85 \\
\hline Learning Objectives and Study Content & 0.85 & 0.89 \\
\hline The instrument of the degree of the & & \\
exercise of human rights principles as a & & 0.89 \\
\hline
\end{tabular}

\subsubsection{Correction of the Questionnaire}

The questionnaire, in its final form, consists of (48) paragraphs divided into three areas: classroom and extracurricular activities, including paragraphs (1-18), the teacher's field of behavior and methods of assessment, including paragraphs 19-34. (1) means that this principle is never used, (2) means the use of the principle rarely, (3) means that the principle is sometimes used, (4) means the use of the principle often, and (5) means always use the principle. To judge the degree of human rights practice from the students' point of view, the computation equation was used by taking the range of responses equal to four, divided by the number of decisions in which the responses are separated, namely 3 decisions (high, medium, and low). Then the resultant value was determined. 1.33 was the cutting point, and it was defined as a criterion for separating scores. Thus, the various levels are shown in Table (5). 


\section{I Macrothink}

Table 5. The average range of the degree of the human rights principles of the teachers of UNRWA schools

\begin{tabular}{|l|l|}
\hline Degree & The average rate that follows \\
\hline High Temperature & $5.00-3.68$ \\
\hline Medium Temperature & $3.68>-2.34$ \\
\hline Low Temperature & $2.34>-1.00$ \\
\hline
\end{tabular}

\subsection{Data Analysis Methods}

For statistical analysis, the SPSS program was used to process the data obtained through the questionnaire used to answer its questions. The mean, the standard deviations, and the grades for each of the scales and each of its domains and for the instrument as a whole were calculated to answer the first question. To answer the second question, three-way analysis of variance MANOVA, and LSD were used for distance comparisons.

\section{Findings and Discussions}

First, the results were related to the first question: What is the degree to which the teachers of UNRWA schools in Jordan are practicing the principles of human rights from the students' point of view?

To answer this question, the mean, standard deviations, degree of practice, and grade were obtained for student responses to each of the paragraphs of the questionnaire and each of its areas and the questionnaire as follows:

A - The responses of the members of the study sample on the areas of the questionnaire and the total degree of the questionnaire: the mean, standard deviations, and levels of responses of the study sample members were extracted at the level of each field and the instrument as shown in Table 6. 


\section{MInstitute ${ }^{\text {Mink }}$}

Table 6 . The mean, standard deviations, the degree of practice, and the levels of the responses of the study sample members to the dimensions of the questionnaire and the questionnaire in a descending order.

\begin{tabular}{|c|c|c|c|c|c|}
\hline Dimension number & $\begin{array}{l}\text { Rank } \\
\text { dimension }\end{array}$ & $\begin{array}{l}\text { The } \\
\text { dimension }\end{array}$ & SMA & $\begin{array}{l}\text { Standard } \\
\text { deviation }\end{array}$ & $\begin{array}{l}\text { Degree of } \\
\text { practice }\end{array}$ \\
\hline 1 & 1 & $\begin{array}{l}\text { Classroom } \\
\text { and } \\
\text { extracurricular } \\
\text { activities }\end{array}$ & 3.80 & 0.77 & High \\
\hline 2 & 2 & $\begin{array}{l}\text { Teacher } \\
\text { behaviors and } \\
\text { methods of } \\
\text { assessment }\end{array}$ & 3.76 & 0.86 & High \\
\hline 3 & 3 & $\begin{array}{l}\text { Learning } \\
\text { Objectives } \\
\text { and Study } \\
\text { Content }\end{array}$ & 3.69 & 0.95 & High \\
\hline \multicolumn{3}{|c|}{ The questionnaire as a whole } & 3.76 & 0.78 & High \\
\hline
\end{tabular}

Table 6 indicates that the first field, classroom and extracurricular activities, received the highest response with an average of 803. A standard deviation (77.0) indicates a high degree in the practice of UNRWA teachers in Jordan for the principles of human rights. Teachers and teachers of UNRWA schools work under the umbrella of one of the international institutions that consider the nature of their work and the principles of human rights and take into account the use of curricula, courses, and activities for students. It also allocates a large part of its budget to support these principles and develop them for students. This, therefore, can also be explained by the Agency's involvement in the Education Reform Program, which aims at "inclusive learning" that supports the integration of students in their different environments, classes, and forms into learning disabilities and challenges. It also facilitates the learning and acceptance of all students as regular students who needs support to achieve optimal learning within the UNRWA system. On the other hand, the second is followed by the teacher's behavior and the methods of evaluation, with an average of 76.3 and a standard deviation of 0.86 . He also indicates a high degree. This may also be attributed to the United Nations Relief and Works Agency. In addition, new evaluation questionnaire s and methods that can be integrated into the socialization processes of the student. Finally, the third area was the learning objectives and the academic content with an average score of 69.3 and a 
standard deviation of 0.95 . It also indicates a high degree. The average response of the sample of the study to the questionnaire was 76.3 and the standard deviation was 78.0 High. This can be explained by the fact that UNRWA, as a body emanating from the United Nations General Assembly, adheres to the principles of human rights and ensures the growth of students in their schools and their education. This can be done based on the principles of human rights through programs that address the issues of these principles. The results of the educational process and the Agency have contributed to the dissemination of the culture of education based on the principles of human rights when asked by the educational services. This, however, is despite the difficult circumstances surrounding the work in recent times. This is also due to the partnership that worked between The United Nations and UNICEF. As a result, this has made it possible to review the Agency's work plans and integrate its activities with activities that promote human rights education. As a result, an open day is held periodically on the basis of support received from UNICEF in UNRWA schools. Thus, they are supporting the work in accordance with the principles of human rights and in ensuring educational development.

B - Responses of the sample members of the study at the level of areas and paragraphs

Means, standard deviations, degree of practice, and grade were calculated for students' responses to each of the paragraphs of the questionnaire and each of its areas as follows:

\section{Field 1: Classroom and extracurricular activities}

The mean, standard deviations, degree of practice, and grade were obtained for the responses of the study sample members at the level of the field vertebrates as shown in Table 7:

Table 7. The mean, standard deviations, degree of practice, and levels of responses of the sample of the study on the fields of classroom and extracurricular activities arranged in a descending order

\begin{tabular}{|l|l|l|l|l|l|}
\hline Rank & $\begin{array}{l}\text { Paragraph } \\
\text { Number }\end{array}$ & Paragraph & Mean & $\begin{array}{l}\text { Deviation } \\
\text { standard }\end{array}$ & $\begin{array}{l}\text { Degree of } \\
\text { Practice }\end{array}$ \\
\hline 1 & 3 & $\begin{array}{l}\text { He answers my } \\
\text { questions to my } \\
\text { colleagues with } \\
\text { respect }\end{array}$ & High \\
\hline 2 & 17 & $\begin{array}{l}\text { He took care of } \\
\text { my safety while } \\
\text { practicing any } \\
\text { activities inside or } \\
\text { outside the }\end{array}$ & 1.23 & High \\
\hline
\end{tabular}




\begin{tabular}{|c|c|c|c|c|c|}
\hline & & classroom & & & \\
\hline 3 & 2 & $\begin{array}{l}\text { Treated me with } \\
\text { respect in front of } \\
\text { my colleagues }\end{array}$ & 4.18 & 1.11 & High \\
\hline 4 & 6 & $\begin{array}{l}\text { My privacy is } \\
\text { respected in the } \\
\text { classroom }\end{array}$ & 4.17 & 1.17 & High \\
\hline 5 & 9 & $\begin{array}{l}\text { He encourages me } \\
\text { to express my } \\
\text { opinion without } \\
\text { shame }\end{array}$ & 4.16 & 1.17 & High \\
\hline 6 & 8 & $\begin{array}{l}\text { He encourages the } \\
\text { exchange of views } \\
\text { among students }\end{array}$ & 4.04 & 1.19 & High \\
\hline 7 & 1 & $\begin{array}{l}\text { He allowed me to } \\
\text { express my views } \\
\text { freely in the } \\
\text { classroom }\end{array}$ & 4.03 & 1.08 & High \\
\hline 8 & 5 & $\begin{array}{l}\text { Respect my } \\
\text { feelings towards } \\
\text { any issue }\end{array}$ & 3.92 & 1.23 & High \\
\hline 9 & 4 & $\begin{array}{l}\text { Involves me in his } \\
\text { activities in the } \\
\text { classroom }\end{array}$ & 3.91 & 1.18 & High \\
\hline 10 & 7 & $\begin{array}{l}\text { He divided us into } \\
\text { activities that } \\
\text { promote } \\
\text { self-respect }\end{array}$ & 3.85 & 1.23 & High \\
\hline
\end{tabular}




\begin{tabular}{|c|c|c|c|c|c|}
\hline 11 & 16 & $\begin{array}{l}\text { He admires my } \\
\text { ideas }\end{array}$ & 3.82 & 1.20 & High \\
\hline 12 & 18 & $\begin{array}{l}\text { Involves me in } \\
\text { recreational } \\
\text { activities and trips } \\
\text { to tourist, natural } \\
\text { and educational } \\
\text { areas }\end{array}$ & 3.73 & 1.43 & Medium \\
\hline 13 & 13 & $\begin{array}{l}\text { Support my } \\
\text { freedom } \\
\text { thought. }\end{array}$ & 3.61 & 1.36 & Medium \\
\hline 14 & 11 & $\begin{array}{l}\text { He undertakes } \\
\text { activities that } \\
\text { promote respect } \\
\text { for human rights }\end{array}$ & 3.58 & 1.37 & Medium \\
\hline 15 & 12 & $\begin{array}{l}\text { Encourages me to } \\
\text { put forward ideas } \\
\text { that support my } \\
\text { freedom of } \\
\text { expression on } \\
\text { school radio }\end{array}$ & 3.50 & 1.42 & Medium \\
\hline 16 & 15 & $\begin{array}{l}\text { Allow me to } \\
\text { express my right } \\
\text { to play my own } \\
\text { games }\end{array}$ & 3.34 & 1.47 & Medium \\
\hline 17 & 14 & $\begin{array}{l}\text { Encourages me to } \\
\text { participate in an } \\
\text { "open day" for } \\
\text { human rights }\end{array}$ & 3.33 & 1.50 & Medium \\
\hline
\end{tabular}




\begin{tabular}{|l|l|l|l|l|l|}
\hline 18 & 10 & $\begin{array}{l}\text { Taking me to } \\
\text { human rights } \\
\text { institutions }\end{array}$ & 1.62 & Medium \\
\hline Domain as a whole & & 3.80 & 0.77 & High \\
\hline
\end{tabular}

Table 7 shows that the statistical means of the responses of the sample of the study sample ranged between 4.38 and 2.64, and the degree of appreciation ranged from high to medium. The table also indicates that the third paragraph "answers my questions to my colleagues with respect" has a high degree, due to teachers 'handling of students' questions as a form of self-assessment. He reflects his questions about the points that may be unclear, which may affect his character later on. Also, respect for the teacher based on the answer to his questions will enhance the confidence of the student himself. It would also encourage others to address any query without fear or Shyness, especially when they see that the debate is full of respectful atmosphere and positive constructive interaction. The tenth paragraph, "Taking me to human rights institutions", received the lowest average score of 2.64. It refers to the average degree of practice. This is due to the difficulty of always coordinating with these organizations and the existence of complicated routine procedures by these organizations to obtain the visit permits. Sometimes, the lack of financial allocations makes the tendency to spend these meager amounts on things more useful than just monitoring the transport of the trip. In addition, the sense of the teacher shows that these visits will take time from after or before his official time to refrain from going out.

Second Field: Teacher Behavior and Evaluation Methods

The mean, standard deviations, degree of practice, and grade were obtained based on the responses of the study sample members at the paragraph level for the second field as shown in Table 8.

\begin{tabular}{|l|l|l|l|l|l|}
\hline Rank & $\begin{array}{l}\text { Paragraph } \\
\text { Number }\end{array}$ & Paragraph & Mean & $\begin{array}{l}\text { Standard } \\
\text { deviation }\end{array}$ & $\begin{array}{l}\text { Degree of } \\
\text { Practice }\end{array}$ \\
\hline 1 & 32 & $\begin{array}{l}\text { Advises and guides students } \\
\text { continuously }\end{array}$ & 4.15 & 1.16 & High \\
\hline 2 & 22 & $\begin{array}{l}\text { Respects my privacy for issues I do } \\
\text { not want anyone to know about }\end{array}$ & 4.09 & 1.26 & High \\
\hline 3 & 34 & $\begin{array}{l}\text { Establishes a relationship based on } \\
\text { mutual respect between him and the } \\
\text { students }\end{array}$ & 3.99 & 1.22 & High \\
\hline 4 & 33 & Offers students' advice & 3.93 & 1.25 & High \\
\hline
\end{tabular}




\begin{tabular}{|c|c|c|c|c|c|}
\hline 5 & 23 & $\begin{array}{l}\mathrm{He} / \text { She tells me about respecting the } \\
\text { rights to life }\end{array}$ & 3.91 & 1.22 & High \\
\hline 6 & 30 & $\begin{array}{l}\text { I wait long enough to hear my } \\
\text { answers to his questions }\end{array}$ & 3.91 & 1.29 & High \\
\hline 7 & 29 & $\begin{array}{l}\text { Taking into account the fairness of } \\
\text { the distribution of questions among } \\
\text { students }\end{array}$ & 3.89 & 1.37 & High \\
\hline 8 & 25 & $\begin{array}{l}\text { They share the rights that interest me } \\
\text { as the right to participate. }\end{array}$ & 3.77 & 1.31 & High \\
\hline 9 & 31 & $\begin{array}{l}\text { He avoids embarrassing students at } \\
\text { school with his questions }\end{array}$ & 3.77 & 1.38 & High \\
\hline 10 & 24 & $\begin{array}{l}\text { Part of his speech to discuss the } \\
\text { importance of the right to a decent } \\
\text { life }\end{array}$ & 3.76 & 1.26 & High \\
\hline 11 & 26 & $\begin{array}{l}\text { Expresses his rejection of violations } \\
\text { of human rights principles }\end{array}$ & 3.75 & 1.31 & High \\
\hline 12 & 21 & $\begin{array}{l}\text { He applies the human rights } \\
\text { principles he discusses with me }\end{array}$ & 3.73 & 1.36 & High \\
\hline 13 & 19 & $\begin{array}{l}\text { Discusses human rights principles } \\
\text { within the classroom }\end{array}$ & 3.63 & 1.35 & Medium \\
\hline 14 & 28 & $\begin{array}{l}\text { I was asked to work on a small } \\
\text { project that supports my } \\
\text { understanding of human rights }\end{array}$ & 3.37 & 1.45 & Medium \\
\hline 15 & 20 & $\begin{array}{l}\text { Discusses the degree of my } \\
\text { knowledge of human rights }\end{array}$ & 3.32 & 1.39 & Medium \\
\hline 16 & 27 & $\begin{array}{l}\text { There are competitions between me } \\
\text { and my colleagues about the } \\
\text { principles of human rights }\end{array}$ & 3.25 & 1.48 & Medium \\
\hline
\end{tabular}


Table 8 shows that the mean of the responses of the study sample members to the teacher's field of behavior and the evaluation methods ranged from 3.25 to 4.15 to a degree of appreciation ranging from high to medium. The table also indicates that the thirty- second paragraph provides advice and guidance to the students (4.15). Also, it shows that the degree of exercise is high due to the desire of the teacher to find a generation that is aware of the meaning of accountability and bears the consequences of their actions. Thus, this is an acceptance of constructive criticism. The opinion which is contrary to them and strengthens their self-confidence, guidance, and criticism is not a derogation to them and their own. However, certain behaviors must be changed, improved or corrected, and this does not demean their dignity, but enhances their personality. The twenty-seventh paragraph, "There are competitions between me and my colleagues on the principles of human rights," have an average of 3.25. This refers to the degree of medium practice because the teacher considers the fact that the competitions may be a waste of time and academic share. He allocates it at his own expense due to the lack of sufficient budgets for such activities. Also, it may deviate from its basic goal to become a mechanism for the instigation of quarrels and a factor of jealousy among students.

Field 3: Learning Objectives and Study Content

The mean, standard deviations, degree of practice, and rank of the responses of the study sample individuals at the paragraph level were extracted for the field of learning objectives, as shown in Table 9:

Table 9. The mean, standard deviations, the degree of practice, and the levels of the responses of the sample members of the study on the areas of the learning objectives and the content of the study are arranged in a descending order.

\begin{tabular}{|l|l|l|l|l|l|}
\hline Rank & $\begin{array}{l}\text { Paragraph } \\
\text { Number }\end{array}$ & Paragraph & Mean & $\begin{array}{l}\text { Standard } \\
\text { deviation }\end{array}$ & $\begin{array}{l}\text { Degree of } \\
\text { practice }\end{array}$ \\
\hline 1 & 37 & Our values develop in helping others & 4.07 & 1.20 & High \\
\hline 2 & 39 & $\begin{array}{l}\text { Emphasizes that the ultimate goal of } \\
\text { human rights is to be good citizens }\end{array}$ & 3.98 & 1.26 & High \\
\hline 3 & 41 & $\begin{array}{l}\text { It focuses on the fact that a decent life } \\
\text { is an important goal in our lives }\end{array}$ & 3.98 & 1.25 & High \\
\hline 4 & 35 & $\begin{array}{l}\text { His concern is that students respect } \\
\text { human rights in their interactions with } \\
\text { each other }\end{array}$ & 3.86 & 1.25 & High \\
\hline 5 & 38 & We are developing noble goals to & 3.81 & 1.28 & High \\
\hline
\end{tabular}




\begin{tabular}{|c|c|c|c|c|c|}
\hline & & consolidate the work of human rights & & & \\
\hline 6 & 40 & $\begin{array}{l}\text { It teaches me to develop my goals to } \\
\text { build a full understanding of human } \\
\text { rights }\end{array}$ & 3.80 & 1.29 & High \\
\hline 7 & 36 & $\begin{array}{l}\text { Emphasizes that the application of } \\
\text { human rights principles is a lofty goal }\end{array}$ & 3.73 & 1.35 & High \\
\hline 8 & 42 & $\begin{array}{l}\text { Offers stories that support lessons that } \\
\text { focus on respect for human rights }\end{array}$ & 3.69 & 1.37 & High \\
\hline 9 & 47 & $\begin{array}{l}\text { Review what we learned in previous } \\
\text { lessons on human rights principles }\end{array}$ & 3.58 & 1.42 & Medium \\
\hline 10 & 43 & $\begin{array}{l}\text { Provides me with materials that } \\
\text { deepens my understanding of human } \\
\text { rights }\end{array}$ & 3.57 & 1.38 & Medium \\
\hline 11 & 45 & $\begin{array}{l}\text { Discusses our problems in an attempt } \\
\text { to deepen human rights }\end{array}$ & 3.53 & 1.40 & Medium \\
\hline 12 & 48 & $\begin{array}{l}\text { The lecture concludes with a useful } \\
\text { phrase or sermon that serves human } \\
\text { rights education }\end{array}$ & 3.41 & 1.52 & Medium \\
\hline 13 & 46 & $\begin{array}{l}\text { Interested in presenting content that } \\
\text { increases our understanding of human } \\
\text { rights such as the Internet, newspaper, } \\
\text { and articles }\end{array}$ & 3.39 & 1.45 & Medium \\
\hline 14 & 44 & $\begin{array}{l}\text { The quota begins with an issue that } \\
\text { emphasizes the principles of human } \\
\text { rights }\end{array}$ & 3.28 & 91.4 & Medium \\
\hline \multicolumn{3}{|c|}{ The whole mean } & 3.69 & 0.950 & High \\
\hline
\end{tabular}

Table 9 shows that the mean of the responses of the individuals in the study sample for the field of learning objectives ranged between 3.28 to 4.07, and the degree of appreciation ranged from high to medium. It also indicates that paragraph 37 develops our values of helping others (4.07). Therefore, this indicates a high degree of practice, due to the teacher's 
desire to develop human relations and values and principles of human rights of students. This, however, means to facilitate the granting of rights to others, and the smooth claim, in the case of deepening the idea of humanitarian assistance to each other. In the end, the forty-fourth paragraph, "The quota begins with the issue of the principles of human rights," with an average of 3.28, indicates a medium level of practice. This is due to the teacher's preoccupation with previous learning based on academic skills associated with the material. The teacher's focus based on the time allocated to the quota may be an obstacle to any dialogues and rights issues. The teacher would prefer to devote this time in working papers, solving questions, and discussing exams. Second is the results of the second question which states: Does the degree of the practice of teachers of UNRWA schools of the principles of human rights vary by gender, grade, and location of the school for students at the level of significance $(\alpha=0.05)$ ?

First: The Questionnaire as a Whole

In answering this question, the mean and the standard deviations of the responses of the sample members of the sample were extracted on the questionnaire as a whole by variables (gender, grade, and school location). This is as shown in Table 10:

Table 10. Mean and standard deviations of students' responses to the total score of the instrument according to gender, grade, and school location

\begin{tabular}{|c|c|c|c|c|}
\hline Number & Variable & Categories & Mean & Deviation Standards \\
\hline \multirow[t]{2}{*}{1} & \multirow[t]{2}{*}{ Gender } & Male & 3.69 & 0.78 \\
\hline & & Female & 3.82 & 0.77 \\
\hline \multirow[t]{4}{*}{2} & \multirow[t]{4}{*}{ Class } & $7^{\text {th }}$ & 3.94 & 0.70 \\
\hline & & $8^{\text {th }}$ & 3.70 & 0.79 \\
\hline & & $9^{\text {th }}$ & 3.67 & 0.79 \\
\hline & & $10^{\text {th }}$ & 3.75 & 0.80 \\
\hline \multirow[t]{2}{*}{3} & \multirow[t]{2}{*}{ School Location } & City & 3.80 & 0.76 \\
\hline & & Camp & 3.70 & 0.79 \\
\hline
\end{tabular}

Table 10 shows that there are apparent differences in the average responses of the sample of the questionnaire as a whole according to the variables (gender, grade, and school location). To find out the direction of these differences, three way MANOVA was used. Table 11. Results of the three-way analysis of the gender impact, grade, and location of the school on the scale as a whole. 


\begin{tabular}{|l|l|l|l|l|r|}
\hline \multicolumn{1}{|r|}{ The source } & $\begin{array}{r}\text { Total } \\
\text { squares }\end{array}$ & $\begin{array}{r}\text { Average } \\
\text { squares }\end{array}$ & $\begin{array}{r}\text { Degrees } \\
\text { of } \\
\text { freedom }\end{array}$ & F Test & $\begin{array}{r}\text { Statistical } \\
\text { significance }\end{array}$ \\
\hline Gender & 16.78 & 6.78 & 1 & 11.40 & 0.00 \\
\hline Class & 21.20 & 7.07 & 3 & 11.88 & .00 \\
\hline Study Location & 1.62 & 1.62 & 1 & 2.72 & 0.10 \\
\hline False & 0.60 & 0.60 & 2499 & 1486.63 & 1521.50 \\
\hline Macro Corrector & & & 2504 & & \\
\hline
\end{tabular}

Table 11 shows statistically significant differences $(\alpha=0.05)$ in the total score of the responses of the study sample members according to the gender variable. In view of the mean, the difference is in favor of females whose responses were average (3.82) (3.69). The results of Table 14 indicate that there are statistically significant differences at the level $(\alpha=0.05)$ in the first field: Classroom and extracurricular activities. The second area: the teacher's behavior and methods of evaluation, and the third area: the objectives of learning and the content of the study of the dimensions of the degree of the exercise of the principles of human rights are also attributed to the gender variable. In view of the mean, it was noted that the difference is in favor of females in those areas. However, they are constantly working on the development of human rights principles, where teachers work to make activities and open days devoted to human rights activities very exciting and exciting for students. However, this may be due to the nature of motherhood characterized by teachers, which would help in the acceptance of students and leads to respect for their rights more than males. This may be because of the fact that the teachers show commitment to comply with civil rights and duties imposed by population socially and emotionally more than males. This is also explained by the fact that female schools in UNRWA are striving for excellence and the application of continuous standards, principles, and educational programs. It seeks to support female students in various ways in demonstrating their role in the population and in supporting their talents. Furthermore, this would give rise to bridge the relationship between male and female students and promote a culture of respect and acceptance. It would also result to partnership and other human rights principles in female schools. Table 11 shows that there are no statistically significant differences at the level $(\alpha=0.05)$ in the total score of the responses of the sample of the study according to the variable of the school site. This may be due to the fact that UNRWA schools operate under one umbrella. Here, these schools are almost different depending on the area in which they are located, , Any UNRWA school in a city or 
camp will have no difference in the nature of the activities in which the teachers, managers, and all of its employees are committed to the principles of human rights.

Table 12. Mean means of the difference, standard error, and statistical significance for the least significant difference (LSD)

\begin{tabular}{|l|l|l|l|l|}
\hline Group & Other Groups & Average difference & Standard error & Statistical significance \\
\hline \multirow{3}{*}{$7^{\text {th }}$ Graders } & $8^{\text {th }}$ & $0.24^{\circ}$ & 0.05 & 0.00 \\
\cline { 2 - 5 } & $9^{\text {th }}$ & $0.27^{\mathrm{o}}$ & 0.05 & 0.00 \\
\cline { 2 - 5 } & $10^{\text {th }}$ & $0.19^{\mathrm{o}}$ & 0.05 & 0.00 \\
\hline \multirow{2}{*}{$8^{\text {th }}$ Graders } & $9^{\text {th }}$ & $0.03^{\mathrm{o}}$ & 0.04 & 0.46 \\
\cline { 2 - 5 } & $10^{\text {th }}$ & $-0.05^{\circ}$ & 0.04 & 0.25 \\
\hline $9^{\text {th }}$ Graders & $10^{\text {th }}$ & $-0.08^{\circ}$ & 0.04 & 0.06 \\
\hline
\end{tabular}

Table 12 shows that there are statistically significant differences $(\alpha=0.05)$ in the response means on the total score of the responses of the members of the study sample according to the variable of the grade among seventh graders and eighth grade students. The results of Table 14 indicate that there are statistically significant differences at the level $(\alpha=0.05)$ in the first field: class and extracurricular activities and the second field: The teacher's behavior and methods of evaluation, and the third field: The objectives of learning and the content of the study of the dimensions of the degree of the exercise of the principles of human rights attributed to the variable class. However, this is due to the nature of developmental characteristics at this stage of late childhood, which is characterized by seventh grade students and an increase in the levels of general intelligence. The ability to interpret events and attitudes surrounding, mental abilities became more accurate in the expression of themselves and the surrounding issues, and can appear in line with what happens to the surrounding environment. Also, it can begin to divide their abilities and preparations based on their understanding and interpretation of what is happening around them. Also, the field of the teacher would help to increase the freedom of students to think, but with the restriction of what is possible and achievable and what is acceptable and what is unacceptable. The focus is increasingly on students in the seventh grade which would help them to overcome some Intellectual determinants, such as the inability to distinguish their point of view or opinion from the point of view or opinion of the group to which he belongs. This is seen especially with the increased growth of abstract thinking and the increase in the ability to infer, deduce, and judge things and solve problems in this stage so as to focus on them more and deeper. 


\section{Macrothink}

Journal of Studies in Education

ISSN 2162-6952

2020, Vol. 10, No. 3

Table 14. MANOVA results of gender impact, grade, and school location in questionnaire areas:

\begin{tabular}{|c|c|c|c|c|c|c|c|}
\hline The source & $\begin{array}{l}\text { Numbe } \\
\text { r }\end{array}$ & $\begin{array}{l}\text { Dependent } \\
\text { variables }\end{array}$ & $\begin{array}{l}\text { Total } \\
\text { square } \\
\text { S }\end{array}$ & $\begin{array}{l}\text { Degree } \\
\mathrm{s} \quad \text { of } \\
\text { freedo } \\
\mathrm{m}\end{array}$ & $\begin{array}{l}\text { Average } \\
\text { squares }\end{array}$ & $\begin{array}{l}\text { F } \\
\text { Test }\end{array}$ & $\begin{array}{l}\text { Statistical } \\
\text { significanc } \\
\text { e }\end{array}$ \\
\hline \multirow{3}{*}{$\begin{array}{l}\text { Gender } \\
(\text { Lambda }= \\
0.992 \mathrm{P}=6.45 \\
\text { level of } \\
\text { significance }= \\
0.000)\end{array}$} & 1 & $\begin{array}{l}\text { Classroom } \\
\text { and } \\
\text { extracurricula } \\
\text { r activities }\end{array}$ & 10.53 & 1 & 10.53 & $\begin{array}{l}18.2 \\
6\end{array}$ & 0.000 \\
\hline & 2 & $\begin{array}{l}\text { Teacher } \\
\text { behaviors and } \\
\text { methods of } \\
\text { assessment }\end{array}$ & 5.29 & 1 & 5.30 & 7.31 & 0.007 \\
\hline & 3 & $\begin{array}{l}\text { Learning } \\
\text { Objectives } \\
\text { and Study } \\
\text { Content }\end{array}$ & 4.55 & 1 & 4.55 & 5.15 & 0.023 \\
\hline \multirow[t]{3}{*}{$\begin{array}{l}\text { Class } \\
(\text { Lambda }= \\
0.984 \mathrm{p}=4.58 \\
\text { significance } \\
\text { level }=0.000)\end{array}$} & 1 & $\begin{array}{l}\text { Classroom } \\
\text { and } \\
\text { extracurricula } \\
\text { r activities }\end{array}$ & 21.44 & 3 & 7.15 & $\begin{array}{l}12.3 \\
9\end{array}$ & 0.000 \\
\hline & 2 & $\begin{array}{l}\text { Teacher } \\
\text { behaviors and } \\
\text { methods of } \\
\text { assessment }\end{array}$ & 22.14 & 3 & 7.38 & $\begin{array}{l}10.1 \\
9\end{array}$ & 0.000 \\
\hline & 3 & $\begin{array}{l}\text { Learning } \\
\text { Objectives } \\
\text { and Study }\end{array}$ & 20.58 & 3 & 6.86 & 7.76 & 0.000 \\
\hline
\end{tabular}




\begin{tabular}{|c|c|c|c|c|c|c|c|}
\hline & & Content & & & & & \\
\hline \multirow{3}{*}{$\begin{array}{l}\text { School } \\
\text { Location } \\
(\text { Lambda }= \\
0.99 \mathrm{p}=1.51 \\
\text { significance } \\
\text { level }=0.21)\end{array}$} & 1 & $\begin{array}{l}\text { Classroom } \\
\text { and } \\
\text { extracurricula } \\
\text { r activities }\end{array}$ & 1.54 & 1 & 1.54 & 2.67 & 0.10 \\
\hline & 2 & $\begin{array}{l}\text { Teacher } \\
\text { behaviors and } \\
\text { methods of } \\
\text { assessment }\end{array}$ & 0.95 & 1 & 0.95 & 1.27 & 0.26 \\
\hline & 3 & $\begin{array}{l}\text { Learning } \\
\text { Objectives } \\
\text { and Study } \\
\text { Content }\end{array}$ & 2.79 & 1 & 2.79 & 3.15 & 0.07 \\
\hline \multirow[t]{3}{*}{ The error } & 1 & $\begin{array}{l}\text { Classroom } \\
\text { and } \\
\text { extracurricula } \\
\text { r activities }\end{array}$ & $\begin{array}{l}1440.9 \\
4\end{array}$ & 2499 & 0.58 & & \\
\hline & 2 & $\begin{array}{l}\text { Teacher } \\
\text { behaviors and } \\
\text { methods of } \\
\text { assessment }\end{array}$ & $\begin{array}{l}1808.7 \\
3\end{array}$ & 2499 & 0.72 & & \\
\hline & 3 & $\begin{array}{l}\text { Learning } \\
\text { Objectives } \\
\text { and Study } \\
\text { Content }\end{array}$ & $\begin{array}{l}2207.9 \\
9\end{array}$ & 2499 & 0.89 & & \\
\hline $\begin{array}{l}\text { Macro } \\
\text { Corrector }\end{array}$ & 1 & $\begin{array}{l}\text { Classroom } \\
\text { and } \\
\text { extracurricula }\end{array}$ & $\begin{array}{l}1479.9 \\
7\end{array}$ & 2504 & & & \\
\hline
\end{tabular}




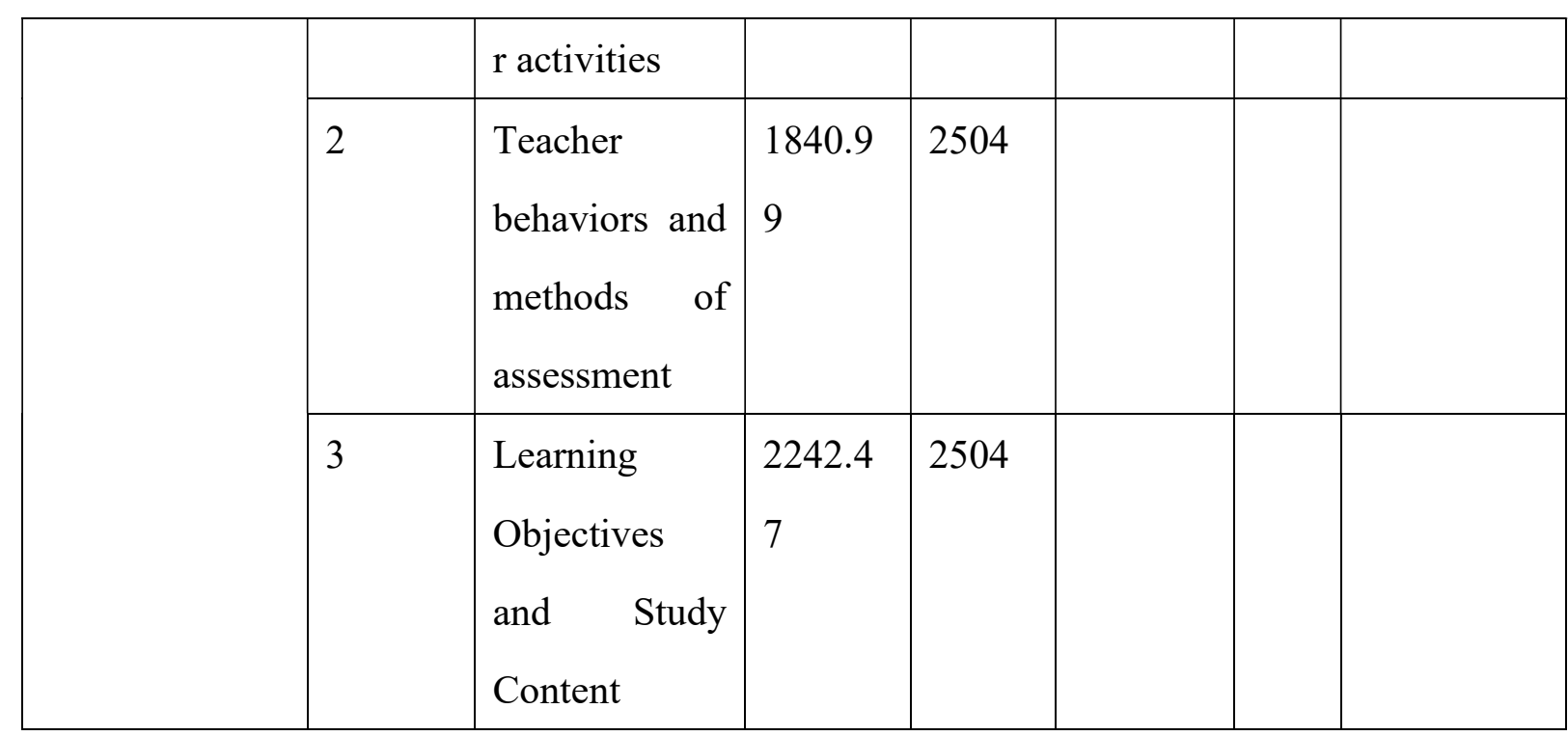

The results in Table 14 indicate that there are statistically significant differences at the level $(\alpha=0.05)$ in the first field: class and extracurricular activities, and the second field: the teacher's behavior and the methods of evaluation. Due to the gender variable, given the mean, the differences in favor of females in these fields are observed. The results in Table 14 indicate that there are statistically significant differences at level $(\alpha=0.05)$ in the first field: classroom and extracurricular activities, and the second field: Human rights were attributed to the variable of the class. Therefore, a less significant difference (LSD) was used to compare the effect of the grade on the degree of human rights practice and to determine the source of differences. Table 15 illustrates this. 


\section{Mll Macrothink}

Table 15. Mean, difference, standard error, and statistical significance for the least significant difference (LSD)

\begin{tabular}{|c|c|c|c|c|c|}
\hline The dimension & Group & $\begin{array}{l}\text { Other } \\
\text { Groups }\end{array}$ & $\begin{array}{l}\text { Average } \\
\text { Differences }\end{array}$ & $\begin{array}{l}\text { The } \\
\text { dimension }\end{array}$ & $\begin{array}{l}\text { Statistical } \\
\text { significance }\end{array}$ \\
\hline \multirow{6}{*}{$\begin{array}{l}\text { Classroom and } \\
\text { extracurricular activities }\end{array}$} & \multirow[t]{3}{*}{$7^{\text {th }}$} & $8^{\text {th }}$ & $0.25^{*}$ & 0.05 & 0.00 \\
\hline & & $9^{\text {th }}$ & $0.26^{*}$ & 0.04 & 0.00 \\
\hline & & $10^{\text {th }}$ & $0.18^{*}$ & 0.05 & 0.00 \\
\hline & \multirow[t]{2}{*}{$8^{\text {th }}$} & $9^{\text {th }}$ & 0.02 & 0.04 & 0.69 \\
\hline & & $10^{\text {th }}$ & -0.07 & 0.04 & 0.10 \\
\hline & $9^{\text {th }}$ & $10^{\text {th }}$ & $-0.09^{*}$ & 0.04 & 0.04 \\
\hline \multirow{6}{*}{$\begin{array}{l}\text { Teacher behaviors and } \\
\text { methods of assessment }\end{array}$} & \multirow[t]{3}{*}{$7^{\text {th }}$} & $8^{\text {th }}$ & $0.25^{*}$ & 0.05 & 0.00 \\
\hline & & $9^{\text {th }}$ & $0.27^{*}$ & 0.05 & 0.00 \\
\hline & & $10^{\text {th }}$ & $0.19^{*}$ & 0.05 & 0.00 \\
\hline & \multirow[t]{2}{*}{$8^{\text {th }}$} & $9^{\text {th }}$ & 0.02 & 0.05 & 0.64 \\
\hline & & $10^{\text {th }}$ & -0.06 & 0.05 & 0.21 \\
\hline & $9^{\text {th }}$ & $10^{\text {th }}$ & -0.08 & 0.05 & 0.08 \\
\hline \multirow{6}{*}{$\begin{array}{l}\text { Learning Objectives and } \\
\text { Study Content }\end{array}$} & \multirow[t]{3}{*}{$7^{\text {th }}$} & $8^{\text {th }}$ & $0.22^{*}$ & 0.06 & 0.00 \\
\hline & & $9^{\text {th }}$ & $0.28^{*}$ & 0.05 & 0.00 \\
\hline & & $10^{\text {th }}$ & $0.21^{*}$ & 0.056 & 0.00 \\
\hline & \multirow[t]{2}{*}{$8^{\text {th }}$} & $9^{\text {th }}$ & 0.06 & 0.051 & 0.24 \\
\hline & & $10^{\text {th }}$ & -0.01 & 0.052 & 0.82 \\
\hline & $9^{\text {th }}$ & $10^{\text {th }}$ & -0.07 & 0.051 & 0.16 \\
\hline
\end{tabular}

Table 15 shows that there are statistically significant differences at the level $(\alpha=0.05)$ in the response means on the first field: class and extracurricular activities among seventh graders, eighth graders, ninth students, and tenth students in favor of seventh graders. Consequently, it has a large share of the activities offered to support the education and culture of human rights principles. Here, school administrations direct and highlight this category for sustainability so that support for students will continue in the classes that students study later. From the beginning of adolescence, they tend to be rebellious, self-assertion, and independent. They are also subjected to more psychological and social conflicts in an attempt to prove itself, which may make it somewhat difficult to provide additional extracurricular activities or classroom. Subsequently, seventh-grade students tend to accept these activities more than the 
nature of social development features here, which make these activities to become a way to interact closer and better with community. Thus, this is the main source of interaction at this stage.

Basically, there are statistically significant differences at the level $(\alpha=0.05)$ in the response means of the second field: the teacher's behavior and the evaluation methods among the seventh grade students on the one hand and the eighth, ninth, and tenth grade students on the other hand were in favor of the seventh grade students. Due to the lack of academic pressure on their curricula between the two stages, the end of the basic minimum stage and the beginning of the basic stage, there is no comprehensive and accurate specialization of the materials yet. This thus allows the teachers to better implement human rights activities and discussions. This helps to create a more flexible and varied methods of evaluation. This result is also due to psychological characteristics of students in the eighth, ninth, and tenth grade characterized by permanent nervous impulse, the foul, stubbornness, the desire to achieve demands, and constant tension in a way that causes great inconvenience to those who deal with them. Also, they are characterized by their tendency to speak harshly and aggressively, and they have a sense of loss of security. This would make teachers to reverse the use of certain behaviors, especially with the intensification of the tendency to be independent and the aspiration to lead and express themselves, feelings, and their desires in inappropriate ways such as shouting, cruelty, sterile debate, involvement in problems, rapid boredom, friction with people, and aversion to advice and persistent stubbornness.

There were statistically significant differences at the level $(\alpha=0.05)$ in the response means on the third field, the learning objectives and the scholastic content among the seventh graders on the one hand and the eighth, ninth, and tenth grade students on the other hand for the seventh graders. This stage, which makes it easier for teachers and teachers to accept them and work with them on human rights than the older students, is also due to the fact that the intellectual structures of the seventh grade students change significantly. In addition, they enter their thinking into the stage of concrete processes and mental events of high degree of complexity such as subtraction, classification or arrangement. Thus, these are related to special experiences and are not abstract or visual. Their thinking is characterized by features such as reverse thinking, retention, sequential order and intellectual transfer, the principle of transformation or infringement, and understanding of relations between different groups. Subsequently, the teacher concentrates on the content of his article and its objectives to link the principles of human rights with the intellectual structure of the student to merge into his mind and become a behavior and values that are present later. There are also statistically significant differences in the response means on the first field: class and extracurricular activities among ninth graders and tenth graders. In view of the mean, the difference was in favor of the tenth-grade students who averaged 3.81. Hence, this is higher than the average of Grade 9 students with average responses (3.72). This is carried out based on the fact that the tenth grade is a final stage of the higher elementary stage. The focus is greater than that of the ninth grade, and the transfer of students after the tenth grade of UNRWA schools may be a contributing factor to focus the attention of teachers on these aspects. This is done in such a way that they will have a significant impact even after they move to another type of Schools. 


\section{MlMacrothink}

Journal of Studies in Education

ISSN 2162-6952

2020, Vol. 10, No. 3

The existence of a larger knowledge-based outcome based on previous experiences on human rights enhances the smooth and easy handling of teachers in this area.

\section{Recommendations}

Considering the findings of the study, which aims at defining the degree of the practice of UNRWA teachers in the field of human rights with their students in Jordan, the following recommendation was given:

1. Encouraging research, projects, and studies that deal with aspects and rights that are easy for students to implement and are passionate about. This is because they are related to their concerns and to their ease of implementation.

2. Emphasize the importance of educating students about human rights by providing them with theoretical information in parallel with applicable behaviors and focusing on developing intellectual and emotional abilities to make moral decisions by exposing them to moral activities that require ethical and moral awareness. Consolidation of the will of the right in themselves should also been given emphasis.

3. Activating the role of the school media in the field of human rights, represented by school radios, schools and the school press. This role combines media and advertising together, and leads to the exit of activities from the routine of the classroom environment to the larger school environment, theater, and drama. The following should be paid attention to: a culture of human rights and practice, providing them with sufficient time for these activities, and giving them more space for integration than a mechanism of the morning queue mechanisms.

4. The extracurricular activities related to human rights should be observed for the educational and psychological foundations of the age groups provided to them, fit with them, not more or less than the age provided to them by the groups of students, and encouraging students to engage in games that develop human rights values, accept them on their own and involve them. In the creation of new human rights games and hear their ideas and proposals and work to implement them within the acceptable and possible, and the selection of human rights games that appeal to students and achieve their tendencies and their own and their entity and suit their preparations and consider individual differences.

\section{References}

Abdul Hamid, F. (2000). Human Rights between Legal Systems and Islamic Law, 1, University Thought House.

Abu Hisham, H., Abdel W. (2013). Level of Awareness of Human Rights and its Relation to Self-Confidence and Confession among Grade 9 Students in Gaza, Unpublished Master Thesis, Al-Azhar University, Gaza, Palestine.

Al-Balawi, S. (2001). Education on Human Rights Reality and Prospects, Al-Aqsa University Journal, Gaza, 144-194.

Amnesty International (2004). Handbook on Human Rights Education, United Nations, New York. 
Ali, Q. (2010). The Role of the School in Spreading the Culture of Human Rights from the point of view of Secondary School Students. Field study in the schools of the official governorate of Damascus, Unpublished MA Thesis, Damascus University, Damascus, Syria.

Al Jarbawi A. (2001). Statement on Human Rights Education, UNRWA, Department of Education.

Arab Organization for Human Rights (2003). Human Rights in the Arab World: Report of the Arab Organization for Human Rights on the Situation of Human Rights in the Arab World, Cairo.

Banks, N. (2001). What Is the State of Human Rights Education in K-12 Schools in the United States in 2000? A Preliminary Look at the National Survey of Human Rights Education. Paper presented at the Annual Meeting of the American Educational Research Association, Seattle, WA, April 10-14-2001.14p.

Cassidy, C., Richard, B., \& Elaine, W. (2014). Teaching Human Rights? All hell will break loose. Education, Citizenship and Social Justice Journal, 9(1), 19-33. https://doi.org/10.1177/1746197913475768

Domo, A. (1990). Terminology of Education Sciences, Al-Resala Press.

Giduri, S. (2012). Tripartite Peace, Dialogue and Tolerance. Reading from an International Educational Perspective, Damascus Center for Theoretical Studies and Civil Rights.

Gronlund, N. (1981). Measurement and Evaluation in teaching, 4th Edition, N Y: Macmillan pub co Inc.

Ishay, M. (2008). The History of Human Rights: From Ancient Times to the Globalization Era, USA: University of California press.

Ismail, S. (1999). Political Vision for Education, Cairo: World Book House. https://doi.org/10.1525/9780520934917

International Conference on Education (1995), Integrated Framework for Action on Education for Peace and Democratic Human Rights, New Education Magazine, Jordan, (58), 205-212.

Jabri, M. (1989). Human Rights in the Maghreb school, as part of the symposium of the National Union of Education, Casablanca, Morocco.

Juliell, V. (2002). Searching for Peace In Europe and Eurasia, London: Lynner Honor Publishers.

Lapayse, A. (2002). The Work of Human Rights Educators: Critical Pedagogy in Action, Unpublished Doctoral Dissertation, University of California, Los Angeles, United States.

Mequni, Y. (2003). Human rights education: an elementary school level case study, unpublished doctoral dissertation, University of Minnesota, Minnesota, United States. 


\section{Macrothink}

Journal of Studies in Education

ISSN 2162-6952 2020, Vol. 10, No. 3

The Ministry of National Education and the Ministry of Human Rights in Morocco. (1998). the special characteristics of the curriculum on human rights education, Educational Supplement of the Socialist Union newspaper.

Mohsen, M. (2004). National Program for Education on Human Rights: A Field Study. Journal of Education, Casablanca, (15), 399-421.

Odigier, F. (1998). Human Rights Education, from the Symposium on the Specialties of the Human Rights Education Curriculum, Educational Supplement of the Socialist Union newspaper.

Omar, I. (2008). Human Rights Knowledge of High School Students in Nablus Governorate Palestine from Teachers' Perspective, MA Dissertation, An-Najah National University, Nablus, Palestine.

Perry, M. (1998). The Idea of Human Rights: Four Inquiries. New York: Oxford University Press.

Potaka, P. (2013). Report on principals sabbatical, Human Rights in Education Initiative (HRIE) in New Zealand, the university of western Australia.

UNRWA (2007). Human Rights Questionnaire kit, Jordan: Human Rights Publications.

United Nations (2005). Office of the High Commissioner for Human Rights and United Nations Development Program, United Nations publications.

Victory Abdel Majeed (2000). Education on Human Rights, Fikr wa Nekd Magazine, Morocco, (30), 63-74. 